研究

\title{
溶融塩法で作製した粉末をホットフォージ法によって配向させた マグネトプラムバイト型フェライトの磁気特性
}

 \\ 41湘南工科大学マテリアル工学科, テ 251-8511 藤沢市过堂西海岸 1-1-25. \\ 的 2 東光 (開発)，广 355-0342 埼玉県比企郡玉川村玉川 828. \\ 43 足利工業大学電気電子工学科, $\overline{\text { T } 326-8558 ~}$ 足利市大前町 268-1.
}

\section{Magnetic Properties of Magnetoplumbite Type Ferrites Crystal-Oriented by Hot-Forging in Air Using Molten Salt Powders}

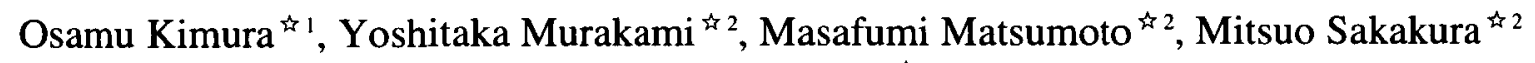 \\ and Kazuo Shoji ${ }^{\text {मे } 3}$ \\ 'Dept. of Materials Science and Engineering, Shonan Institute of Technology, 1-1-25 Nishikaigan Tsujido, Fujisawa 251-8511. \\ 4 2 Development Department, Toko Co. INC. Ltd., 828 Tamagawa Tamagawa Hiki-gun, Saitama 355-0342. \\ ${ }^{3}$ Dept. of Electrical and Electronics Engineering, Ashikaga Institute of Technology, 268-1 Omae Ashikaga 326-8558.
}

Received April 8, 2002

\begin{abstract}
SYNOPSIS
Magnetic properties were studied for magnetoplumbite type ferrites, namely, $\mathrm{Z}, \mathrm{W}$ or $\mathrm{Y}$ type hexagonal ferrites, whose basal planes contain the easy direction of magnetization. Increase in the degree of crystal orientation of these ferrites is known as an effective method to enhance their permeabilities. Accordingly, we have already obtained highly crystal-oriented samples by applying a hot-forging process in air, using normally calcined powders as starting materials. Here, a molten-salt process is adopted to prepare new powders of the ferrites composed of plate-like particles. The degrees of crystal orientation of the hot-forged samples are expected to enhance by replacing the normally calcined powders with these powders.
\end{abstract}

KEY WORDS

Magnetoplumbite ferrites, permeability, crystal orientation, hot-forging, molten-salt process

\section{1 まえがき}

最近，電子デバイスの小型化と高周波化に伴って，電子部 品のダウンサイジングが求められている. それに対応して, 積㒶型のチップインダクタが磁性素子として広く使用されて いる. また, 携帯電話を始めとして GHz 帯で使用される機器 も実用化され，コンピュータなどもますます高周波化しつつ ある. 現在, 主として研究されている高周波磁性材料はマグ ネトプラムバイト型の六方晶フェライトで, 特にZ 型が注目 されている. 本研究では $\mathrm{Z}$ 型のみならず，水平磁化特性を有 していることが知られている” $\mathrm{Y}$ 型およびW 型に着目し，前 報 ${ }^{2)}$ と同様にホットフォージ法を用いて粒子配向し，磁気特 性を調べた．ただし，使用した粉末は溶融塩法によって作製 した. 溶融塩法は板状に配向した粉末を得るためには有効な 方法であって，電子セラミックスには多く用いられており ${ }^{31}$, Ba フェライト"), Y 型フェライトラの粉末作製も試みられてい る.

\section{2 試料および実験方法}

高純度 $\mathrm{BaCO}_{3}, \mathrm{CoO}, \mathrm{NiO}, \mathrm{MgCO}_{3}, \mathrm{ZnO}, \mathrm{Fe}_{2} \mathrm{O}_{3}$ の粉末を仮焼 後はおのおの, $\mathrm{Co}_{2} \mathrm{~W}\left(\mathrm{BaO} \cdot 2 \mathrm{CoO} \cdot 8 \mathrm{Fe}_{2} \mathrm{O}_{3}\right), \mathrm{Co}_{2} \mathrm{Z}(3 \mathrm{BaO} \cdot 2 \mathrm{CoO} \cdot$ $\left.12 \mathrm{Fe}_{2} \mathrm{O}_{3}\right), \mathrm{Co}_{2} \mathrm{Y}\left(2 \mathrm{BaO} \cdot 2 \mathrm{CoO} \cdot 6 \mathrm{Fe}_{2} \mathrm{O}_{3}\right), \mathrm{Ni}_{2} \mathrm{Y}\left(2 \mathrm{BaO} \cdot 2 \mathrm{NiO} \cdot 6 \mathrm{Fe}_{2} \mathrm{O}_{3}\right)$, $\mathrm{Mg}_{2} \mathrm{Y}\left(2 \mathrm{BaO} \cdot 2 \mathrm{MgO} \cdot 6 \mathrm{Fe}_{2} \mathrm{O}_{3}\right), \mathrm{Zn}_{2} \mathrm{Y}\left(2 \mathrm{BaO} \cdot 2 \mathrm{ZnO} \cdot 6 \mathrm{Fe}_{2} \mathrm{O}_{3}\right)$ の組成 になるように秤量し， $\mathrm{ZrO}_{2}$ ボールを用いて湿式混合し，乾燥 した.

その後, $\mathrm{Y}$ 型フェライトの場合 ${ }^{5)}$ と同样に, 㙁として $\mathrm{K}_{2} \mathrm{SO}_{4}$ (蜃点 $1069^{\circ} \mathrm{C}$ ) を用い，粉体と塩の比率を $\mathrm{W}$ と $\mathrm{Z} 1: 1, \mathrm{Y}$ は $2: 1$ の重量比で混合し, W と Z $1250^{\circ} \mathrm{C}, Y$ Y $1200^{\circ} \mathrm{C}$ で $1 \mathrm{~h}$ 仮焼し, 冷却後, 塊を解碎し, 塩化バリウムを加えても白沈 が生じなくなるまで, 熱湯で洗净した。これにPVAを1\%混 合し，150MPa の圧力で成形し，13 $\mathrm{mm}$ ，高さ $10 \mathrm{~mm}$ の月筒 体を作製した。これを 2 枚の白金簿 $(0.2 \mathrm{~mm}$ 厚)に挟み，窒化 珪素を介して大気中高温下で30分間25-30MPaで加圧しホッ トフォージした. ホットフォージ温度はWとZは 1250,1270 , $1290^{\circ} \mathrm{C}, \mathrm{Y}$ は $1220,1240^{\circ} \mathrm{C}$ とした. ホットフォージ終了後, 加 


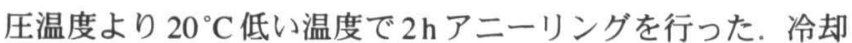
後, 試料をトロイダル状に加工し, $1.8 \mathrm{GHz}$ までの複素透磁率 $\mu=\mu^{\prime}-\mathrm{j} \mu$ "をインピーダンスアナライザを用いて測定した. な お，透磁率 $\mu, \mu \mathrm{Q}$ 積で用いている $\mu$ はここで言う $\mu^{\prime}$ のことで ある. また, 試料の表面及び断面のSEM 観察を行い, 粒径と 配向状況を調べた. また, アルキメデス法によって密度を求め た。さらに, 試料の X 線回折図から Lotgering が提案した式 ${ }^{6)}$ を用いて $\mathrm{c}$ 軸の配向度 $\mathrm{f}$ を求めた。

$$
\mathrm{f}=\frac{\mathrm{p}-\mathrm{p}_{0}}{1-\mathrm{p}_{0}}, \quad \mathrm{p}=\frac{\sum \mathrm{I}_{001}}{\sum \mathrm{I}_{\mathrm{hkl}}}
$$

ここで, $\mathrm{I}_{\mathrm{hkl}}$ および $\mathrm{I}_{001}$ は $(\mathrm{hkl})$ 面および $(001)$ 面の $\mathrm{X}$ 線回折強 度で, $\mathrm{p}_{0}$ は未配向の試料の值であり, 本研究では実測值の代 わりにJCPDS カードの值を用いた。

\section{3 実験結果および考察}

Fig.1に $\mathrm{Co}_{2} \mathrm{Z}(\mathrm{A})$ および $\mathrm{Co}_{2} \mathrm{Y}(\mathrm{B})$ の溶融塩法で得られた粉末 のSEM写真を示す。前者には $10 \mu \mathrm{m}$ を超える大きい粒子も見 られるが, 平均して 5-10 $\mu \mathrm{m}$ の六角板状晶からなっており, 後者は $5 \mu \mathrm{m}$ 程度の六角板状晶となっているのが見いだされ る. Fig. 2 に $\mathrm{Co}_{2} \mathrm{Z}(\mathrm{A})$ および $\mathrm{Co}_{2} \mathrm{Y}(\mathrm{B})$ の粒子の $\mathrm{X}$ 線回折図を示 す. $\mathrm{Co}_{2} \mathrm{Z}$ 粉末ではZ相中にわずかにY相が残留しているの が見いだされるが,一方, $\mathrm{Co}_{2} \mathrm{Y}$ 粉末は完全にY相単相になつ ていることがわかる。ただし $\mathrm{K}^{+}$と $\mathrm{Ba}^{2+}$ のイオン半径はそれ ぞれ $0.133 \mathrm{~nm}$ と $0.136 \mathrm{~nm}$ とほぼ同一であるため, 溶融塩中の $\mathrm{K}^{+}$からのコンタミネーションが生じる可能性があり, EPMA を用いて焼成品中の $\mathrm{K}$ 含有率を分析した結果を Table 1 に示 す.これによると $\mathrm{Y}$ 系のコンタミネーションは数\%以下であ るが, ZとWのコンタミネーションは10\%に達しているので, これによる影響があるものと考えられる.

Fig.3に各温度でホットフォージした試料の磁気特性の周波 数依存性を示す. $\mathrm{Y}$ 系では $1220^{\circ} \mathrm{C}$ でホットフォージした試料



(A)
の透磁率は $1240^{\circ} \mathrm{C}$ でホットフォージした試料の透磁率より低

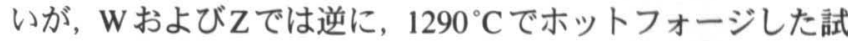
料の透磁率が最も低い。これは前報 ${ }^{2)}$ の通常仮焼粉末を用い
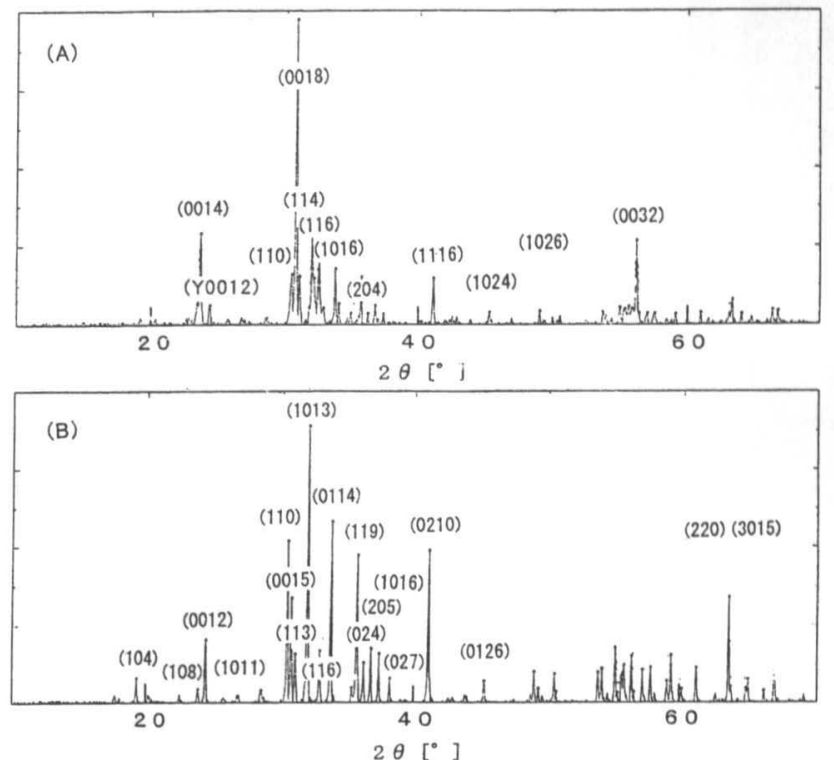

Fig.2 (A) $\mathrm{X}$ ray diffraction pattern of the $\mathrm{Co}_{2} \mathrm{Z}$ powder prepared by the molten salt process. (B) $\mathrm{X}$ ray diffraction pattern of the $\mathrm{Co}_{2} \mathrm{Y}$ powder prepared by the molten salt process.

Table 1 Kalium contents (wt \%) of molten salt powders expressed as $\mathrm{K} / \mathrm{Ba}+\mathrm{K}$ (Temperatures indicate their calcined temperatures).

\begin{tabular}{|c|cccccc|}
\hline Type & Co2W & $\mathrm{Co} Z$ & $\mathrm{Co} Y$ & $\mathrm{Ni} 2 Y$ & Mg2Y & Zn2Y \\
\hline Temperature & $1250^{\circ} \mathrm{C}$ & $1250^{\circ} \mathrm{C}$ & $1200^{\circ} \mathrm{C}$ & $1200^{\circ} \mathrm{C}$ & $1200^{\circ} \mathrm{C}$ & $1200^{\circ} \mathrm{C}$ \\
$\mathrm{K} /(\mathrm{Ba}+\mathrm{K}) \%$ & 12.9 & 9.5 & 3.3 & 4.4 & 3.8 & 2.6 \\
\hline
\end{tabular}

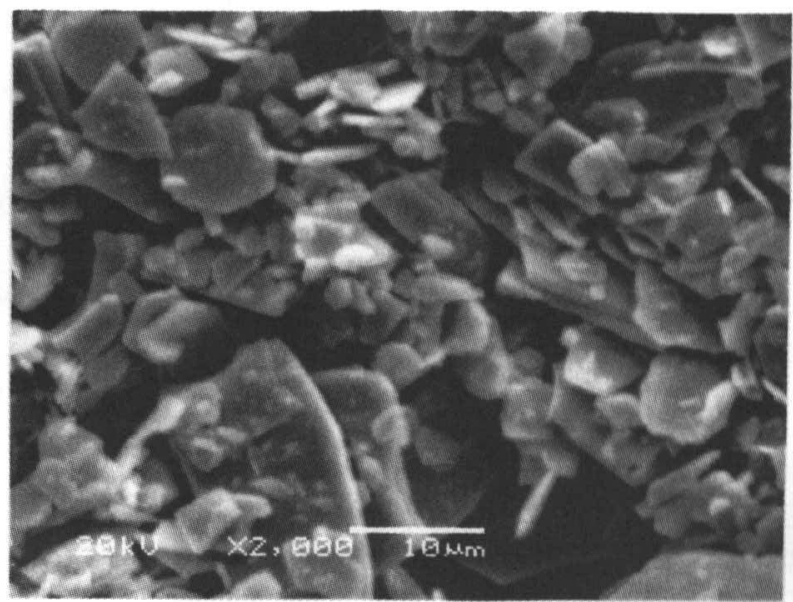

(B)

Fig.1 (A) SEM photograph of the $\mathrm{Co}_{2} \mathrm{Z}$ powder prepared by the molten salt process. (B) SEM photograph of the $\mathrm{Co}_{2} \mathrm{Y}$ powder prepared by the molten salt process. 

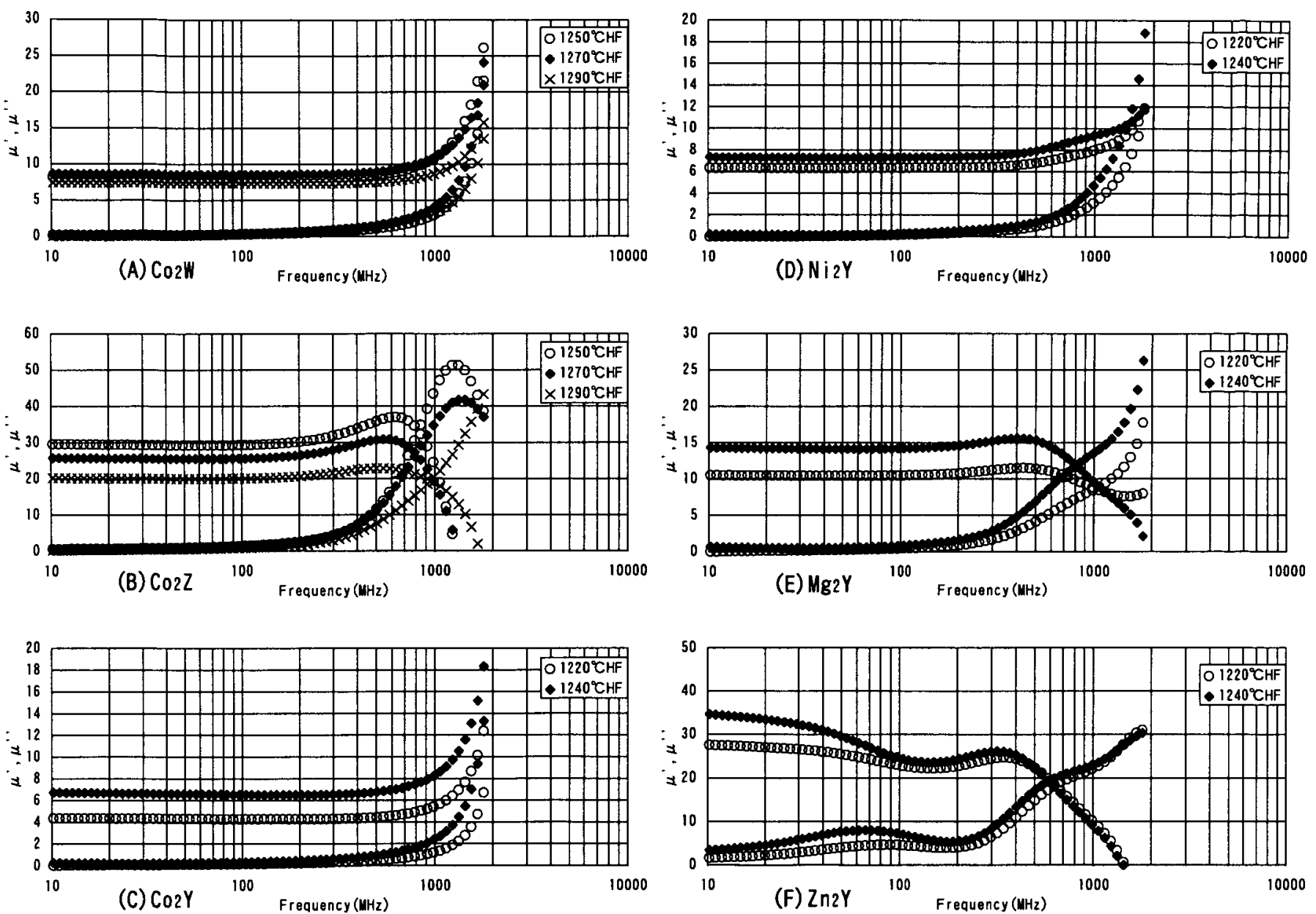

Fig.3 Frequency dependencies of $\mu^{\prime}$ and $\mu^{\prime \prime}$ for the samples hot-forged at various temperatures, (A) $\mathrm{Co}_{2} \mathrm{~W},(\mathrm{~B}) \mathrm{Co}_{2} \mathrm{Z},(\mathrm{C}) \mathrm{Co}_{2} \mathrm{Y},(\mathrm{D}) \mathrm{Ni}_{2} \mathrm{Y}$, (E) $\mathrm{Mg}_{2} \mathrm{Y}$, (F) $\mathrm{Zn}_{2} \mathrm{Y}$.

てホットフォージした試料には見られなかった現象である. そこでTable 2 に最高温度でホットフォージした試料(A)の配 向度, 密度, 磁気特性を示す. また, 比較のために前報2)の通 常仮焼粉末を用いてホットフォージした試料(B)の值も示す. $\mathrm{Co}_{2} \mathrm{~W}$ や $\mathrm{Co}_{2} \mathrm{Z}$ では通常仮焼粉末をホットフォージした試料と 比較すると, $1290^{\circ} \mathrm{C}$ では密度や配向度は殆ど同一の高い值に 達しているが，透磁率の值はWでは $10 \%$ 程度，Zでは $30 \%$ 程 度低い。これはKイオンのコンタミネーションの影響と考え られる. Table 3 に $\mathrm{Co}_{2} \mathrm{~W}(\mathrm{~A})$ と $\mathrm{Co}_{2} \mathrm{Z}(\mathrm{B})$ の諸特性の処理温度に よる変化を示す，まず, Wでは好理温度が低下すると, 密度 は若干低下するが, 配向度は95\%以上と高い值である.これ は出発粒子の形状によるものと考えられる. また, $300 \mathrm{MHz}$ おける透磁率は $1270^{\circ} \mathrm{C}$ で焼成した試料が 8.7 と最も高く, 通 常粉末の $1290^{\circ} \mathrm{C}$ の試料より高い. さらに, $1250^{\circ} \mathrm{C}$ の試料も 8.0 と高い值を示している. また, $\mathrm{Z}$ では $1270^{\circ} \mathrm{C} や 1250^{\circ} \mathrm{C} て ゙$ 焼成した試料は配向度も $90 \%$ あ, 透磁率はそれぞれ 27.9 と 31.7 之通常仮焼粉末の $1290^{\circ} \mathrm{C}$ 試料に匹敵する値を示してい る. これらは出発原料の形状が板状であれば, 低温でも十分 ホットフォージ配向し, 高い透磁率が得られることを意味し
ている.

一方，Y系では通常仮焼粉末の試料より配向度は低く，期 待されたような板状粉末の効果が得られなかった。また，密 度も通常仮焼粉末の試料より低かった。これは通常仮焼粉末 は微粉砕されているため, 粒径が $0.1-0.2 \mu \mathrm{m}$ と極めて微細で あったのに対し ${ }^{2)}$, 溶融塩法粉末が $5 \mu \mathrm{m}$ 以上と粗大であった ことによるものと考えられる. しかし，透磁率は逆に通常仮


$\mathrm{Ni}_{2} \mathrm{Y}$ で6.8から7.5へ, $\mathrm{Mg}_{2} \mathrm{Y}$ で 10.1から15.2へ, $\mathrm{Zn}_{2} \mathrm{Y}$ で 24.1 から26.1 へと向上している.これは, 後に示すSEM観察の結

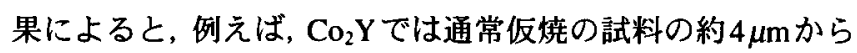
溶融塩法の試料の $7 \mu \mathrm{m}$ へと粒成長しているように, 出発粒子 が大きいため, 最終粒子も大きくなるためと考えられる.

Fig.4 および Fig.5に $\mathrm{Co}_{2} \mathrm{Z}$ および $\mathrm{Co}_{2} \mathrm{Y}$ の各ホットフォージ 温度における $\mathrm{X}$ 線回折図を示す.これらの回折図はホット フォージ軸に対して垂直な表面に対して得られたものである. まず, $\mathrm{Co}_{2} \mathrm{Z}$ では前報 ${ }^{2)}$ の通常仮焼の試料では W 相が $1290^{\circ} \mathrm{C}$ で初めて 10\%程度成長してきたのに対し，この溶融塩法の試

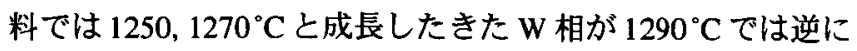


Table 2 Magnetic properties of the samples hot-forged at maximum temperatures.

(A) Molten salt powders as starting materials.

(B) Normally calcined powders as starting materials')

(A)

\begin{tabular}{|c|c|c|c|c|c|c|}
\hline Type & $\mathrm{CO} 2 \mathrm{~W}$ & $\mathrm{CozZ}$ & $\mathrm{Co} Y \mathrm{Y}$ & $\mathrm{Ni}_{2} \mathrm{Y}$ & $\mathrm{Mg}_{2} \mathrm{Y}$ & $2 n 2 Y$ \\
\hline Temperature & $1290^{\circ} \mathrm{C}$ & $1290^{\circ} \mathrm{C}$ & $1240^{\circ} \mathrm{C}$ & $1240^{\circ} \mathrm{C}$ & $1240^{\circ} \mathrm{C}$ & $1240^{\circ} \mathrm{C}$ \\
\hline$D C O \%$ & 99 & 96 & 71 & 60 & 55 & 67 \\
\hline TD $\quad \mathrm{g} / \mathrm{cm}^{3} \quad$ D & 5.33 & 5.35 & 5.35 & 5.38 & 5.12 & 5.41 \\
\hline ensity $\mathrm{g} / \mathrm{cm}^{3}$ & 5.26 & 5.28 & 5.29 & 5.18 & 4.89 & 5.24 \\
\hline$\mu$ зоомнг & 7.4 & 21.6 & 6.6 & 7.5 & 15.2 & 26.1 \\
\hline Q300月H & 8.7 & 7.2 & 10.7 & 9.7 & 5.3 & 3.1 \\
\hline$\mu Q_{\text {зоонин }}$ & 64 & 155 & 70 & 72 & 81 & 81 \\
\hline$\mu 16 \mathrm{~Hz}$ & 8.7 & 18.8 & 8.3 & 9.4 & 9.6 & 9.1 \\
\hline Q $\mathrm{IGH}_{2}$ & 2.7 & 0.9 & 3.4 & 1.9 & 0.7 & 0.4 \\
\hline$\mu 0,1 \mathrm{GHz}_{2}$ & 23.2 & 17.2 & 28.5 & 18.2 & 6.8 & 3.6 \\
\hline $\mathrm{fC} \mathrm{GH}_{2}$ & $>1.8$ & 0.95 & $>1.8$ & 1.5 & 0.8 & 0.59 \\
\hline
\end{tabular}

(B)

\begin{tabular}{|c|c|c|c|c|c|c|}
\hline Type & Co2W & Co22 & $\mathrm{Co} 2 \mathrm{Y}$ & $\mathrm{Ni} 2 \mathrm{r}$ & $\mathrm{Hg}_{2} \mathrm{Y}$ & $\mathrm{Zn} 2 \gamma$ \\
\hline Temperature & $1290^{\circ} \mathrm{C}$ & $1290^{\circ} \mathrm{C}$ & $1240^{\circ} \mathrm{C}$ & $1240^{\circ} \mathrm{C}$ & $1240^{\circ} \mathrm{C}$ & $1240^{\circ} \mathrm{C}$ \\
\hline$D C O \%$ & 96 & 94 & 76 & 74 & 80 & 92 \\
\hline TD $\quad \mathrm{g} / \mathrm{cu}^{3} \quad \mathrm{D}$ & 5.33 & 5.35 & 5.35 & 5.38 & 5.12 & 5.41 \\
\hline ensity $\mathrm{g} / \mathrm{C \textrm {C } ^ { 3 }}$ & 5.29 & 5.13 & 5.37 & 5.42 & 5.14 & 5.41 \\
\hline$\mu$ зо0लHz & 8.2 & 32.9 & 4.4 & 6.8 & 10.1 & 24.1 \\
\hline Q3000Hz & 12.6 & 3.3 & 14.9 & 7.8 & 4.2 & 3.6 \\
\hline$\mu 0_{300 \mathrm{Hнz}}$ & 103 & 107 & 66 & 53 & 42 & 86 \\
\hline$\mu 1 \mathrm{GHz}$ & 10.1 & 10.6 & 5.3 & 7.9 & 7.5 & 10.9 \\
\hline $\mathrm{O} \mathrm{IGHZ}_{2}$ & 3.3 & 0.4 & 3.8 & 1.7 & 1.1 & 0.5 \\
\hline$\mu Q_{1} \mathrm{GH}_{2}$ & 33.1 & 3.7 & 20.5 & 13.4 & 8.2 & 5.8 \\
\hline fo $\mathrm{GHZ}_{2}$ & $>1.8$ & 0.63 & $>1.8$ & 1.4 & 1.1 & 0.68 \\
\hline
\end{tabular}

* OCO is the degree of crystal orientation.

** ID is the theoretical density".

*** $f c$ is the cut-off frequency where $Q=1$.

Table 3 Magnetic properties of $\mathrm{CO}_{2} \mathrm{~W}$ and $\mathrm{Co}_{2} \mathrm{Z}$ hot-forged at $1250^{\circ} \mathrm{C}$, $1270^{\circ} \mathrm{C}$ and $1290^{\circ} \mathrm{C}$, respectively.

\begin{tabular}{|c|c|c|c|c|c|c|}
\hline Type & \multicolumn{3}{|c|}{ Co2W } & \multicolumn{3}{|c|}{ Co2z } \\
\hline Temperature & $1250^{\circ} \mathrm{C}$ & $1270^{\circ} \mathrm{C}$ & $1290^{\circ} \mathrm{C}$ & $1250^{\circ} \mathrm{C}$ & $1270^{\circ} \mathrm{C}$ & $1290^{\circ} \mathrm{C}$ \\
\hline $0 C 0 \%$ & 95 & 94 & 99 & 93 & 87 & 96 \\
\hline TD $\quad g / \mathrm{cn}^{3} \quad D$ & 5.33 & 5.33 & 5.33 & 5.35 & 5.35 & 5.35 \\
\hline ensity $\mathrm{g} / \mathrm{cm}^{3}$ & 4.99 & 5.05 & 5.26 & 5.09 & 5.11 & 5.28 \\
\hline$\mu$ зо0нHнz & 8.1 & 8.7 & 7.4 & 31.7 & 27.9 & 21.6 \\
\hline Q300MHz & 12.5 & 9.3 & 8.7 & 7.4 & 6.8 & 7.2 \\
\hline$\mu 0_{300 \mathrm{HHz}}$ & 102 & 81 & 64 & 236 & 188 & 155 \\
\hline$\mu 1 \mathrm{GHz}$ & 10.8 & 10.9 & 8.7 & 23.7 & 18.8 & 18.8 \\
\hline Q $1 \mathrm{GHz}$ & 3.6 & 2.7 & 2.7 & 0.5 & 0.5 & 0.9 \\
\hline$\mu Q_{1 G \mathrm{~Hz}}$ & 39 & 29.1 & 23.2 & 12.7 & 10.1 & 17.2 \\
\hline$f \circ \mathrm{GHZ}^{2}$ & $>1.8$ & 1.7 & $>1.8$ & 0.83 & 0.80 & 0.95 \\
\hline
\end{tabular}

* OCO is the degree of crystal orientation.

** TD is the theoretical density"

*** $\mathrm{fc}$ is the cut-off frequency where $Q=1$
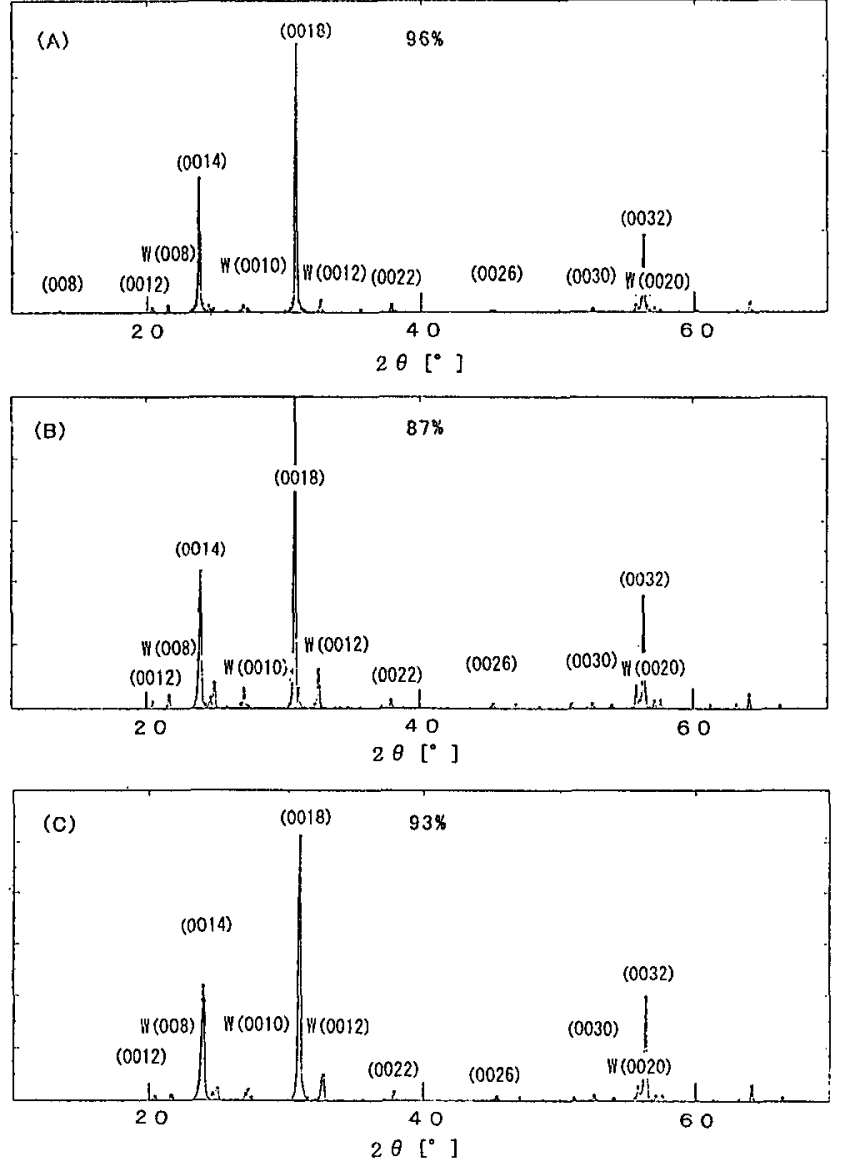

Fig.4 $\mathrm{X}$ ray diffraction patterns of the hot-forged $\mathrm{CO}_{2} \mathrm{Z}$ samples. (A) $1290^{\circ} \mathrm{C} \mathrm{HF}$, (B) $1270^{\circ} \mathrm{CHF}$, (C) $1250^{\circ} \mathrm{CHF}$.
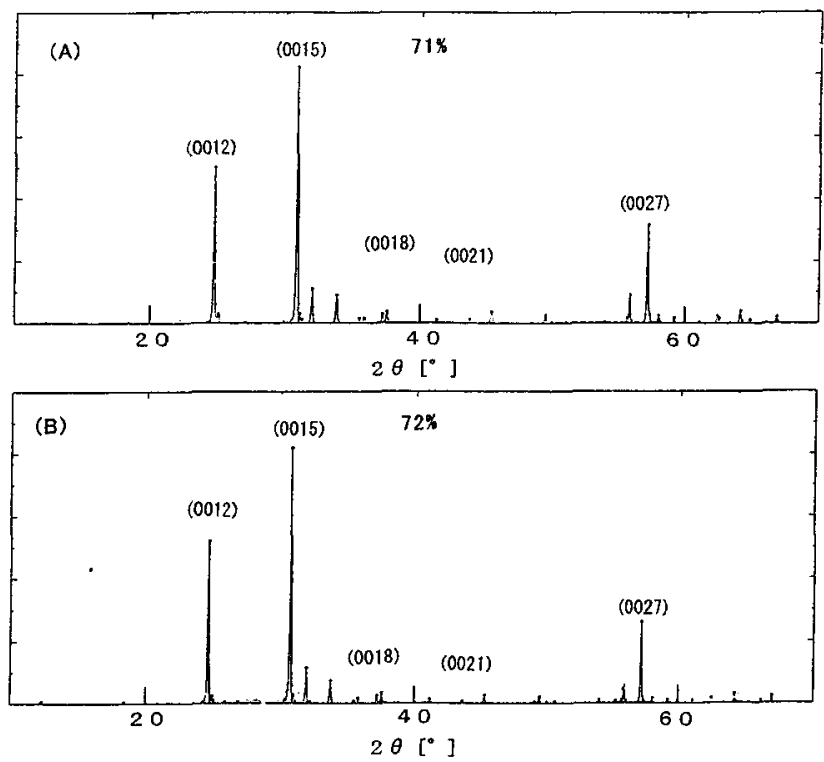

Fig.5 X ray diffraction patterns of the hot-forged $\mathrm{Co}_{2} \mathrm{Y}$ samples. (A) $1240^{\circ} \mathrm{CHF},(\mathrm{B}) 1220^{\circ} \mathrm{CHF}$ 
減少している.これはKイオンコンタミネーションの影響に よるものと考えられる。 また, 通常仮焼の試料では配向度は 温度が $1250,1270,1290^{\circ} \mathrm{C}$ と上昇するに従い, $63 \%, 80 \%, 94 \%$ と向上しており ${ }^{2}$, 温度上昇に伴い塑性変形による配向が生じ ていると考えられるが, 溶融塩法の試料ではほぼ90\%以上と 配向度は処理温度と殆ど関係がない。これは出発原料の形状 異方性によって配向が生じているためである. その点は $\mathrm{Co}_{2} \mathrm{Y}$ に関しても同様であって, 溶融塩法品の配向度は $1220^{\circ} \mathrm{C}$ と $1240^{\circ} \mathrm{C}$ の試料はほぼ同一である. ただ, 配向度が $70 \%$ 程度で 向上しないのは, 粒子の塑性流動が不十分なためと推定され る.


よび $1240^{\circ} \mathrm{C}$ でホットフォージした $\mathrm{Co}_{2} \mathrm{Y}$ のホットフォージ軸 に垂直な表面 (A) および断面 (B) の SEM 写真を示す. $\mathrm{Co}_{2} \mathrm{Z}$ で は平均 $10 \mu \mathrm{m}$ の板状の粒子が表面にほぼ垂直に形成されてい るのが見いだされ, 配向度の高さと対応している. 空孔の大 きさも小さく, 十分に高密度化していることがわかる. 一方, $\mathrm{Co}_{2} \mathrm{Y}$ の方はやはり, 板状の粒子が形成されてはいるが, ホット フォージ軸に対して完全には垂直でないので, これが配向度 が低い值しか示さない原因であろう。これはY系では粒子の 塑性流動が不十分なためと考えられる.しかし, 粒径が $7 \mu \mathrm{m}$ 程度に成長しているので, これが上述したように配向度の低

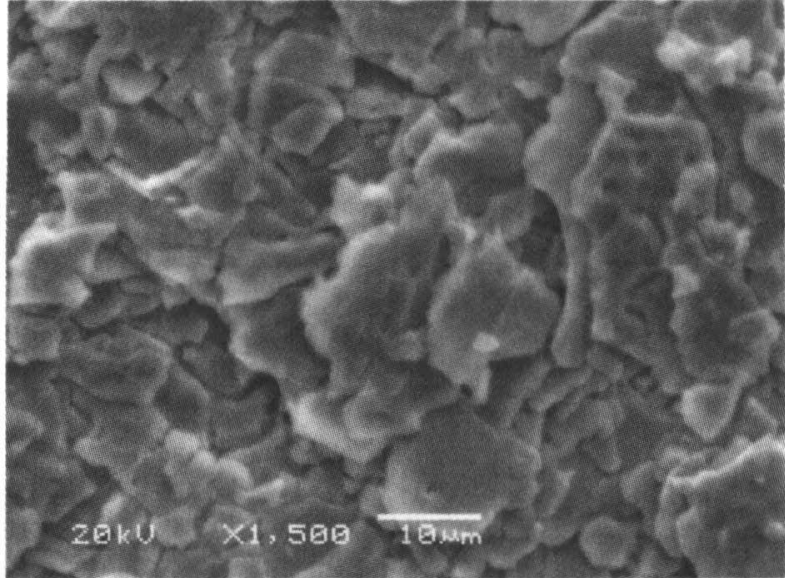

(A)

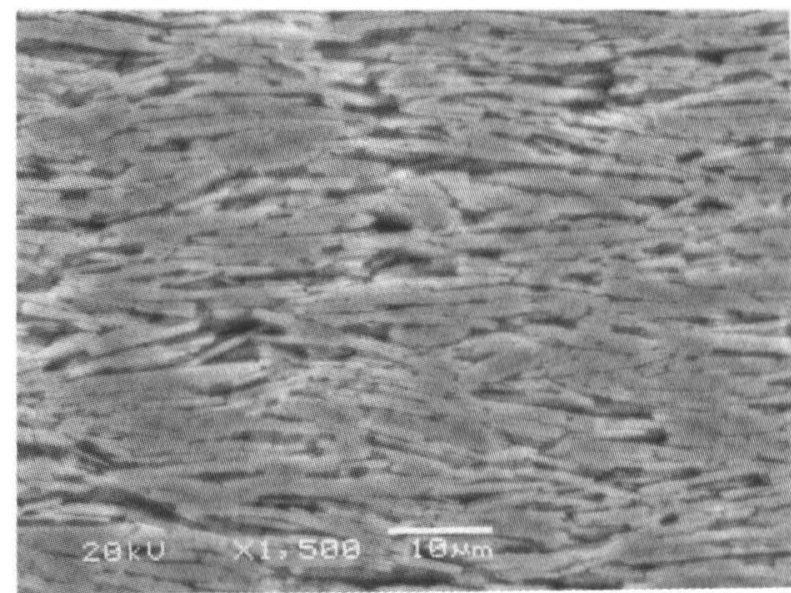

(B)

Fig.6 SEM photographs of the $\mathrm{Co}_{2} \mathrm{Z}$ sample hot-forged at $1290^{\circ} \mathrm{C}$.

(A) The surface perpendicular to the hot-forging axis. (B) The cross section.

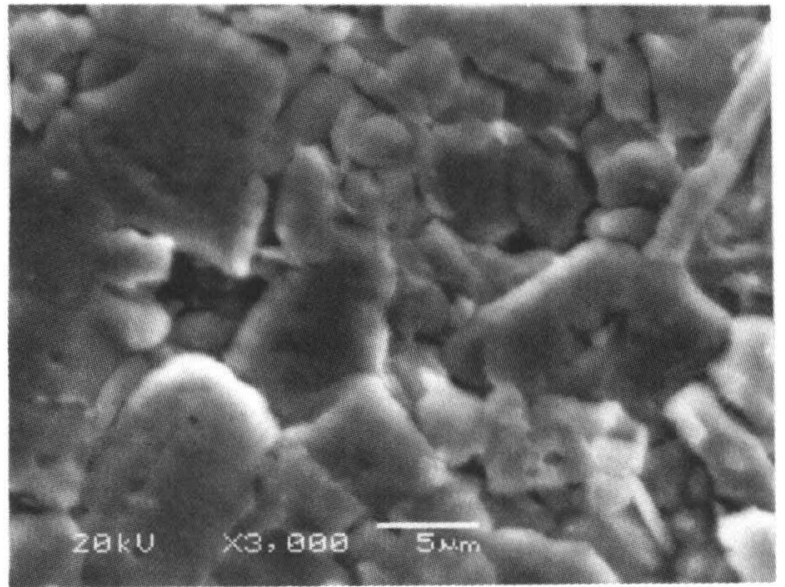

(A)

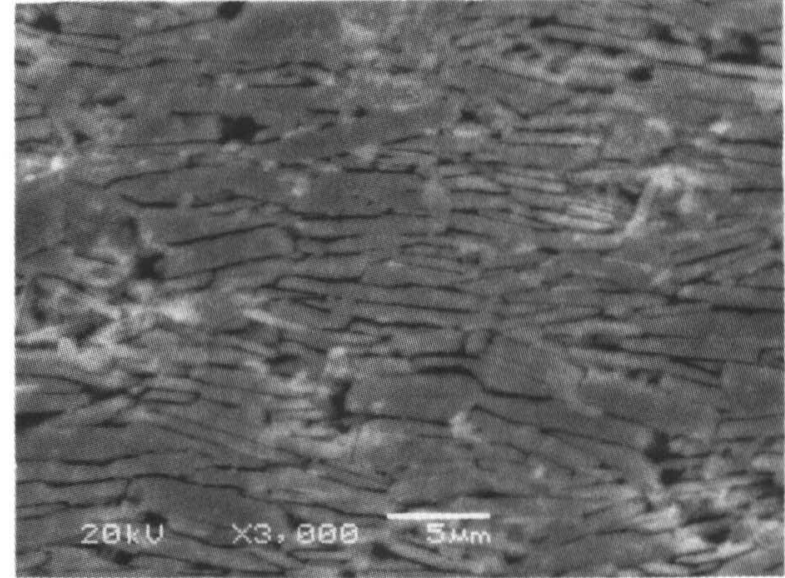

(B)

Fig.7 SEM photographs of the $\mathrm{Co}_{2} \mathrm{Y}$ sample hot-forged at $1240^{\circ} \mathrm{C}$.

(A) The surface perpendicular to the hot-forging axis. (B) The cross section. 
さにも拘わらず高い透磁率が得られた理由であろう．

\section{4 まとめ}

水平磁化特性を有するW，Z, Y 型のマグネトプラムバイト型 フェライトの粉末を溶融塭法を用いて板状粒子を作製するこ

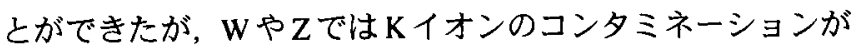
顕著であった。この粉末を用いてホットフォージ法によって, c軸配向させたところ, $\mathrm{Z} や W て ゙ は$ 低いホットフォージ温度で 通常仮焼粉末を用いた場合と同一の透磁率が得られ，Y型で は最高温度で通常粉末の試料よりも高い透磁率が得られた。 これは板状粒子の効果と考えられるが，WやZの高温での磁 気特性のより一層の向上を目指すには溶融塩によるコンタミ ネーションの防止が必要である. また, また, 配向度はホッ トフォージ温度に殆ど無関倸に，WやZでは $90 \%$ 以上の配向 度が得られたが，Y 型では通常仮焼粉末を用いた場合と同様 高い配向度に達しなかった，Y型の配向度の向上は今後の課 題である.
文献

1) G.H.Jonker, H.P.J.Wijn and P.B.Braun: "FERROXPLANA FERRIMAGNETIC IRON OXIDE...", Philips Tech. Rev., 18 (1956/57)145-154.

2）木村修, 松本雅史, 坂倉光男, 荘司和男: “大気中ホット フォージ法によって配向させたZ型マグネトプラム‥", 粉 体および粉末冶金, 49(2002)114-119.

3) M.Holmes, R.E.Newnham and L.E.Cross: "Grain-Oriented Ferroelectric Ceramics", J. Amer. Ceram. Soc. Bull., 58(1979)872.

4) R.H.Aredt: "The Molten Salt Synthesis of Single Magnetic Domain $\mathrm{BaFe}_{12} \mathrm{O}_{19}$ Crystals", J. Solid. State. Chem., 8(1973)339-347.

5）栗原弘, 成宮義和, 茂呂英治: “軟磁性六方晶フエライト焼 結体の製造方法", 日本特許, 2717815(1990).

6) F.K.Lotgering: "TOPOTACTICAL REACTIONS WITH FERRIMAGNETIC …", J. Inorg. Nucl. Chem., 9(1959)113-123.

7) R.R.Arons et al: "LANDOLT-BOERNSTEIN", Gruppe III Band 12, Springer-Verlag, Berlin, (1982)584, 593, 606. 